\title{
THE RESPONSE TO CHALLENGING BEHAVIOR AS A BARRIER TO SOCIAL INCLUSION ERASMUS+ PROJECT PARTICIPANTS' PERSPEC- TIVES ON POLICY AND PRACTICE
}

\author{
ROLF MAGNUS GRUNG ${ }^{1}$, ANNA ODROWAZ-COATES ${ }^{2}$, JUDE TAH ${ }^{3}$, PAUL MALORET ${ }^{4}$, \\ JULIEN KISS 5 , \& FLORICA ORTAN ${ }^{6}$
}

\footnotetext{
${ }^{1}$ OsloMet - Oslo Metropolitan University, Department of Behavioral Science, Postboks 4, St. Olavs plass, 0130 Oslo, Norway. ORCID: 0000-0002-0400-4688, Email: rgrung@oslomet.no

${ }^{2}$ The Maria Grzegorzewska University, Social Pedagogy Department, Szczesliwicka 40, 02-353 Warsaw, Poland. ORCID: 0000-0002-2112-8711, Email: acoates@aps.edu.pl

3 Stockholm University, Department of Special Education, Frescati Hagväg 10 (Frescati Hage) Stockholm University, SE-106 91 Stockholm, Sweden. ORCID: 0000-0002-2593-4243, Email: jude.tah@specped.su.se

${ }^{4}$ University of Hertfordshire, Department of Nursing, Midwifery and Social Work, Hatfield, United Kingdom AL10 9AB, UK. ORCID: 0000-0003-2184-0642, Email: p.b.maloret@herts.ac.uk

${ }^{5}$ University of Oradea, Department of Teacher training, University Street Nr. 1, Oradea, Romania. ORCID: 0000-0003-4038-6297, Email: julien.kiss@uoradea.ro

${ }^{6}$ University of Oradea, Director of Teacher Training Department, University Street Nr. 1, Oradea, Romania. ORCID: 0000-0001-5972-6322, Email: flortan@uoradea.ro
}

ABSTRACT: The paper is the result of collaboration between seven European universities and covers health, social pedagogy, and special education programs, aimed at the removal of barriers to social inclusion and social participation facing children and young adults with intellectual and developmental disabilities (IDD). The collaboration received funding from the Erasmus+ Intensive Program with the aim of developing a common curriculum on social inclusion for children and young adults with IDD. Identifying variables that support inclusion for individuals with IDD who engage in challenging behavior is critically important and this paper is built on reviewing social and educational policies from 5 European countries in order to do so. The paper re- 
veals loopholes and paradoxes in policy that hinder social inclusion when addressing challenging behavior. The greatest challenges identified by the researchers are the gaps in training for different professions and the lack of overarching legislation for these professions. Another issue identified is government tolerance of a lack of clear competencies and codes of conduct amongst unregulated service providers.

KEYWORDS: developmental disabilities, ethics, collaboration, international comparative studies, policy

\section{INTRODUCTION}

$\mathrm{I}^{\mathrm{n}}$ n this paper we aim to focus on challenging behavior as a barrier for social inclusion of children and young people with intellectual and developmental disabilities (IDD). However, as a result of the critical reflection, we ascertain that it is coercive practice in response to challenging behavior that may be responsible for hindering inclusion. We discuss relevant national legislation from contributing European countries and specific professional approaches to challenging behavior from a practitioner's perspective. We discuss professional perspectives that our team represents and therefore social educators (Norway), special pedagogues (Poland, Romania, Sweden) and learning disability nurses (UK) are at the focus, as they are positioned at the center of our professional experience. Coincidently, we unveil controversial paradoxes, entangled in the interplay between national legislation on social inclusion and human rights, and the use of legal coercion in professional practice. Therefore, the overall aim of our article is to highlight the gaps and grey areas in policy and practice that addresses challenging behavior that may create barriers to the social inclusion of people with IDD in the five European countries we explore (Norway, Sweden, United Kingdom, Poland, and Romania ${ }^{1}$ ).

Although enhancing social inclusion is one of the important aims in professional practice, it is inhibited by problem behavior. Problem behavior may sometimes lead to use of coercion (physical force, the use of power or restraint against a person's will). The legal use of force and coercion as a measure to reduce the negative consequences of problem behavior creates a barrier to social inclusion and carries a stigma. Is there an alternative to the use of legal coercion, especially when the use of coercion is prolonged? In Norway, legal decisions on the use of force and constraints (Health and Care Service Act 2011) are valid up to 12 months, but there are no limitations on how many times a person with IDD may experience the lawful use of enforcement measures. As a result, if a decision to use force is extended, a person may spend their entire life under such conditions. This is an extremely difficult issue to resolve if the aim is

\footnotetext{
${ }^{1}$ Participating universities: Oslo Metropolitan University from Norway, The Maria Grzegorzewska University from Poland, The University of Oradea from Romania, The University of Hertfordshire from England, Stockholm University from Sweden, Edinburgh Napier University from Scotland and The Queens University of Belfast from Northern Ireland.
} 
indeed social inclusion. In this paper we analyze country-specific policies related to the different professions involved and investigate how social inclusion principles and the use of legally justified force are balanced. When a vulnerable group in society displays challenging behavior, the response should come from highly trained professionals, as there is a difference between stopping the person using peaceful measures and coercion, which would be stopping the person using physical force (e.g. pinning them down to the floor). Competent practitioners are trained to use the right procedures at the right moment.

Health, social, and educational professionals have a politically agreed mandate from society to provide services to the vulnerable, a mandate mirrored in the ethical guidelines developed by each profession. One purpose of these guidelines is to give society confidence that teachers, nurses etc. are able to deliver what's expected from them (Grimen 2008). Broadly speaking, the purpose of ethical guidelines is to direct each profession so that it contributes to delivering of the mandate given to the profession by the society. Issues related to self-determination, avoiding intrusive measures, and quality of life are central to these ethical guidelines (FO 2019). However, many professionals experience, often on a daily basis, that the use of force, constraints and other intrusive measures applied against the will of an individual (all of which constitute coercion), are observed in secure services. This may be viewed as exercising power entrusted in professionals by society (mandate for professions of trust), but also erects a mental barrier between staff and the service users (cf. Goffman 1978). In our view, it also undermines trust of service users towards staff, enhances negative stereotypes and stereotypical responses to difficult situations, and it may stigmatize both staff and service users in the eyes of wider society. Thus, a tension between the need for intrusive measures on the one side and self-determination on the other side easily occurs. In this tension ethical issues and legal demands related to social inclusion and quality of life exist, which each profession and professionals need to securely solved and met. Moreover, appropriate training on how to resolve difficult situations where challenging behavior occurs is key to supporting the sustainable social inclusion of persons with IDD and reducing the need for use of coercion. In a systematic review of staff training on challenging behavior for individuals with intellectual disability, Cox, Dude and Temple (2014), identified positive behavior support, active support, appropriate communication training and using alternative and augmentative communication as relevant areas for professional training, which yield positive outcomes in mitigating challenging behavior. Due to the international and multilingual context of this paper we enclose a table with the glossary of terms we use and how they should be understood. 


\begin{tabular}{|l|l|}
\hline Term & Definition \\
\hline ity - Intellectual and developmental disabil- & $\begin{array}{l}\text { Severe, chronic condition with mental and/or } \\
\text { physical impairments that affect self-care, inde- } \\
\text { pendence, mobility, ability to express oneself and } \\
\text { to learn, often described as SEN (special educa- } \\
\text { tional needs) or SEDN (special educational needs } \\
\text { and disabilities) }\end{array}$ \\
\hline Coercion & $\begin{array}{l}\text { Use of physical force, restrains, application of } \\
\text { medication or preventive and punitive measures } \\
\text { against one's will. }\end{array}$ \\
\hline Special pedagogue & $\begin{array}{l}\text { Special pedagogue is a university-trained special- } \\
\text { ist able to support the holistic development and } \\
\text { learning of persons with SEDN (In Romania also a } \\
\text { psychopedagogue) }\end{array}$ \\
\hline Social educator/social pedagogue & $\begin{array}{l}\text { In some countries, social pedagogues support indi- } \\
\text { viduals with SEDN in their independence and in- } \\
\text { clusion within the community. In other countries, } \\
\text { they build theoretical frameworks and commun- } \\
\text { ty-based solutions for social work to be delivered } \\
\text { (cf. Odrowaz-Coates \& Szostakowska 2021) }\end{array}$ \\
\hline Social inclusion & $\begin{array}{l}\text { Social participation, which means equality of ac- } \\
\text { cess to all spheres of social life, social interactions } \\
\text { of vulnerable people and people within wider soci- } \\
\text { ety that is frequent and meaningful. }\end{array}$ \\
\hline
\end{tabular}

Table 1. Terminology

Source: own elaboration.

\section{CHALLENGING BEHAVIOR}

The term "challenging behavior" was originally introduced by The Association for People with Severe Handicaps in North America and is often related to people with intellectual and developmental disabilities (IDD). Other terms are also used among practitioners to label such behavior, such as "aberrant behavior", "dysfunctional behavior", "maladaptive behavior" and "problem behavior". However, the term "challenging behavior" is the preferred term among experts within the field because it brings fewer negative connotations and is not associated with any deviating psychological factors (Emerson 2001). Emerson (1995; as cited in Emerson 2001) defines challenging behavior as:

[...] culturally abnormal behavior(s) of such intensity, frequency or duration that the physical safety of the person or others is likely to be placed in serious jeopardy or behavior which is likely to seriously limit the use of, or result in the person being denied access to, ordinary facilities. (p. 3).

Different studies confirm the prevalence of challenging behavior in people with IDD and describe it as high, but the reported prevalence between them varies (Simó-Pinatella et al. 2019; Grung et al. 2021). Some possible explanations for this diversity are variations in the operationalization of challenging behavior, characteristics of the samples, and variation in measurement methodology. For instance, in a systematic 
review based on 20 prevalence studies of challenging behavior in children and young people with IDD, Simó-Pinatella et al. (2019) found an overall prevalence rate ranging from $48 \%$ to $60 \%$ in children diagnosed with intellectual disabilities. In children diagnosed with autism spectrum disorder (ASD) Simó-Pinatella et al. found an overall prevalence rate of challenging behavior at about 90\%. The latter is not a surprise as some types of stereotypical behavior, which can include challenging behavior, are a diagnostic criterion in ASD (World Health Organization 2020).

In a prevalence study conducted with a Norwegian sample, Holden and Gitlsen (2006) found challenging behaviors in 11.1\% $(\mathrm{N}=91)$ of 904 participants with IDD. The most common forms of challenging behavior were attacking other people $(6.4 \%$, $\mathrm{N}=53)$, self-injurious behavior $(4.4 \%, \mathrm{~N}=36)$ and destructive behavior $(2.3 \%, \mathrm{~N}=19$. 7.1\% ( $\mathrm{N}=59)$. Participants also displayed other difficult, disruptive or "socially unacceptable behavior'. Furthermore, Holden and Gitlesen (2006) found that challenging behavior occurred more often in males than in females and that challenging behaviors were more common in people under the age of 40 . They also found that the prevalence of challenging behavior increased with the severity of intellectual disabilities. Similar to Simó-Pinatella (2019), Holden and Gitlesen (2006) found that challenging behavior was more prevalent in people with ASD and even more so in people living in municipal care homes (community-based care homes supported by the state or the local authority within the community, to support independent living, grow in popularity in Norway, Sweden, UK and in the past 5 years also in Poland). Holden and Gitlsen (2006) also found that there was a correlation between impaired communication skills and an increased likelihood of challenging behavior. This may be due to frustration experienced by individuals unable to express their needs.

\section{SOCIAL INCLUSION}

Literature and research on social inclusion has been criticized for lack of a coherent definition of the concept (Bigby 2012). For example, in a thematic analysis of key contributors to social inclusion, Filia et al. (2018) referred to 17 different definitions of social inclusion. However, for the purpose of this paper social inclusion is understood as "social participation between vulnerable people and people within wider society that is frequent and meaningful, such as frequent and meaningful social interactions and relationships between children with IDD and their peers without disabilities" (Grung et al. 2021: 1).

Social exclusion, the opposite of social inclusion, has severe negative effects on the individual and their cognitive processes (cf. Ask et al. 2019; Syrjämäki \& Hietanen 2019), his or her close relations (family) and on the society (cf. Twenge et al. 2001; Baumeister et al. 2002; Bernstein 2016). For such an individual, social exclusion has negative effects on all aspects of their life, from their perceived quality of life to biological parameters such as higher blood glucose, due to negative behavioral patterns pertaining to health (Floyd et al. 2016). In this context, it is worth noting that social inclusion/exclusion are the most important determinants of health and wellbeing (Wilkinson \& Marmot 1998). For close relatives, the experience that their loved ones 
are socially excluded can be a very stressful situation whilst for society, social exclusion is associated with a significant economic burden (Parodi \& Sciulli 2012). Social inclusion is a proven method to reduce these burdens (Boushey et al. 2007, as cited in Filia et al. 2018). For example, social inclusion policies such as minimum wages, tax-reduction for low-income earners, flexible employment and work measures improving labor market participation, do not only increase individual income and wellbeing but importantly, also boost economic growth. Therefore, social inclusion has major positive effects on health, wellbeing, and quality of life for people with IDD (Floyd et al. 2016). To define social inclusion, one may look at it from a multitude of perspectives, for instance an educational perspective (e.g. access to education with neurotypical peers), or from a civil/human rights perspective (e.g., access to the community, supported living and the ability to enter employment). Different pieces of legislation support each of these types of inclusion.

\section{COERCION AS A BARRIER FOR SOCIAL INCLUSION}

As described by Emerson (2001) in his definition of challenging behavior, one of the consequences of such behavior is that it is "[...] likely to seriously limit the use of, or result in the person being denied access to, ordinary facilities” (p. 3). Thus, challenging behavior is by definition a risk factor for social exclusion (cf. Bigby 2012; Holden \& Gitlesen 2006). Typical examples of challenging behavior displayed by people with IDD are aggressive behaviors towards others (physical- and verbal aggression), self-injurious behavior (i.e. face hitting, biting own arms), a higher frequency of stereotyped behavior (i.e. hand flapping, stereotyped vocalization), severe hygiene challenges (i.e. encopresis, enuresis), and pica (i.e. eating inedible things) (cf. Emerson 2001; Holden \& Gitlesen 2006). Such behavior may be a danger to the individual and to other people, may inhibit important training and can hinder that person's opportunity for meaningful social interaction with others (i.e. social inclusion) (Holden \& Gitlesen 2006). Despite declarations and treaties related to human rights (United Nations, 2006) and national legislation and policies (Grung et al. 2021), many children and young adults with IDD continue to experience social exclusion (Bartolo et al. 2016). The use of coercion may be part of the issue. Social inclusion is built on the principle of overcoming existing differences and distinctions for overall social benefit. In situations when a representative of one group holds power to use coercive force over another, this principle is undermined, drawing a clear demarcation line between the service providers and the service users (cf. Goffman 1971). How can this aid inclusion? Regarding the issue of inclusion, Hem et al. $(2014: 7 ; 2018)$ found that perceived coercion is related to a more negative patient-therapist relationship, building a barrier to social inclusion. On the other hand, the safety of the person displaying challenging behavior and the personnel concerned is equally important.

There is a general expectation in societies that professionals who provide services to people with IDD, either within education or health and social services, have the formal competence to do so and a strong ethical grounding (Grimen 2008). However, a Swedish study (Sjöstrand et al. 2015) showed that the law is subject to a broad range 
of interpretations in the hands of professionals, who, using implicit over explicit coercion, manipulate patients' autonomy, through using power in negotiations, bargaining and the use of blackmail. Another study from Sweden, concerning ethical arguments for use of coercion in the treatment of children and adolescents with IDD, focused on two main considerations: protection and treatment requirements (Pelto-Piri at al. 2016). These were most often judged and justified on the authority of facility staff and the decision of carers within the closest family (Pelto-Piri at al. 2016). The ethics of compulsory treatment was analyzed in the context of human rights by Stevens (2012), who concluded that the use of coercion may be appropriate, based on professional judgment. However, his study referred to drug abusing offenders and not people with IDD. In a recently published study, Ellingsen et al. (2020) found that as many as $33.2 \%$ of the service providers within municipal health and social services directed at people with IDD in Norway, did not have any relevant formal training. Furthermore, they found that $38.6 \%$ had relevant educational training at a lower level (high school), and that only $28.2 \%$ had the relevant higher education. Of those, $10.7 \%$ had training as social educators. They also found that the number of part-time positions was high and that more than $50 \%$ of staff with no relevant formal training and education worked less than ten hours per week. Still, in these ten hours, a challenging behavior may occur and a lack of training may lead to an abuse of power.

A central purpose within the training provided by the Norwegian social educator program is to ensure that the candidate has "competence related to disabilities and the social conditions that create disability, [and] competence related to complex needs and developmental disabilities" (Kunnskapsdepartementet 2019; § 2, the authors' translation). The social educator program is the only program with higher-education training that explicitly focuses on the needs of people with IDD. However, disabilities in general are not the sole responsibility of social educator training. As part of the focus on disabilities in general, and specific to the needs of people with IDD, social inclusion is a central topic in the social educator curriculum. It cuts across as a lite motif through all the subjects in the curriculum. In addition, since challenging behavior is relatively prevalent within people with IDD (cf. Holden \& Gitlesen 2006; Simó-Pinatella et al. 2019), legislation relevant to the use of force and coercion is focused on during social educator training (Kunnskapsdepartmenet 2019).

As described earlier, there is legislation on the use of force and coercion that explicitly applies to people with IDD in Norway. The professional code for social educators states that even if the conditions for the legal use of coercion and force are present, it may not be ethically responsible to do so (FO 2019). Hem et al. (2014) focused on the consequences for staff health, resulting from the burden of making decisions about the use of coercive force, which they classed as: formal, informal and perceived coercion. All of these cases carried an emotional burden for the user of coercive force. The question as to how to provide what is in the best interest of the 'patient' and the service provider remains open. Bach \& Kerzner (2010), Danzer \& Rieger (2016), Norvoll, Hem \& Pedersen (2017) tried to present a user-focused approach as more beneficial and less harmful for all the social agents involved, but did not discuss the implications for social inclusion per se. They centered around 'will and preferences', as well as 'best 
interests', but found that these matters could be very subjective and related to the values held by the individuals involved. Therefore, the values of the service users and the professional code of ethics should be considered. Values that may or may not have been tailored by professional ethics and codes of conduct (cf. Bach \& Kerzner 2010). This also applies to the possible harmful or positive outcomes of decisions regarding the use of force.

\section{LEGISLATION AND POLICIES IN FIVE EUROPEAN COUNTRIES}

This section contains brief summaries of the relevant legislation of each of the above-mentioned countries regarding health, special education and social services aimed at children and young adults with IDD and challenging behavior. It is important to be aware that this is not a systematic review, but a purpose driven overview of key points where human rights and policy interact, sometimes in conflicting ways.

\section{NORWAY}

In Norway both policy and practice are based on rights, starting with the Right to special education. Pupils who do not have, or cannot receive a satisfactory outcome from ordinary education are entitled to special education (Opplæringslova 1998). Furthermore, the Act on Right to services and treatment (Pasient- og brukerrettighetsloven 1999) dedicated to patients' and users' rights gives children and young adults (and others with Norwegian citizenship), the right to necessary treatment from specialist health care services (such as hospitals and ambulatory health services provided by the hospitals) and the necessary healthcare services from the local municipality (Pasient- og brukerrettighetsloven 1999). The term 'necessary' should in this context be understood as the right to appropriate and secure services based on a specific assessment of the need for such services (adequate, appropriate, relevant, right competence, at the right time, at the right place etc; Helsedirektoratet 2015). While the Specialist healthcare services primarily focus on the treatment of challenging behavior, the health and care services from the local municipalities, which also provides housing and respite services if necessary, focus primarily on care and the facilitation of everyday activities. However, the facilitation of everyday activities may contain elements of treatment. Cooperation between the two levels of health care services is a legal obligation, which will be described later. The right to contribution, to information and to consent, influenced the Act on patients' and users' rights, which gives children and young adults with IDD the right to contribute to all stages of the services/treatment provision. In practical terms, the contribution means being included in the decision making about themselves and their treatment. Depending on the age of the child and their cognitive abilities, legal representatives (most often parents) may contribute along with the child. Information about the services and treatment is crucial for both the fulfillment of the right to contribution and the right to consent. If the young adult is over 16 , the main rule is that it's that person who consents to the healthcare services, independent of the diagnosis. However, this is modified by the persons' cognitive abilities, and in some cas- 
es, consent is given by their legal representatives (Pasient- og brukerrettighetsloven 1999). The legislation on the right to consent is complex and in this paragraph, only a short outline has been given. The rights to contribute, to be given information and to consent, applies to all kinds of treatment and care services, including the treatment of challenging behavior. The right to an individual plan and coordinator, gives patients and users who are in need of long term and coordinated healthcare services, the legal right to an individual plan (IP) and a coordinator (pasient- og brukerrettighetsloven 1999). An IP is a collaboration plan between different health and social services and a mechanism that facilitates contribution from the patient or user for whom the services are provided. An IP is coordinated by a coordinator, someone who is a professional, frequently in contact with the patient and the user, and his/her legal representatives and close relatives. There are also some instances where coercion may be used.

\section{LEGISLATION ON THE USE OF COERCION IN NORWAY}

Today there are four different acts on the use of coercion and all may apply to people with IDD:

(i) patients that lack the ability to consent and who actively refuse healthcare measures (Pasient- og brukerrettighetsloven 1999); Chapter 4 a)

(ii) coercive measures against drug addicts (Helse- og omsorgstjenesteloven 2011); Chapter 10) (iii) establishment and termination of compulsory mental health care (Psykisk helsevernloven 1999; Chapter 3), and

(iv) the use of coercion and force against certain persons (Helse- og omsorgstjenesteloven 2011; Chapter 9).

However, work is ongoing in Norway to renew the legislation on the use of coercion. A likely outcome of this work is that the four acts will be replaced by one act on the use of coercion (NOU 2019: 14). The use of coercive measures against people with IDD are mostly regulated by Chapter 9 in the Health- and Care Service Act (Helse- og omsorgstjenesteloven 2011). This act applies to people with IDD of all ages during delivery of services from the local municipality. The purpose is to prevent persons with IDD from exposing themselves or others to significant harm and to prevent and limit the use of coercion. Central in this act is the fact that the use of coercion is the last resort, and measures not involving coercion must be evaluated and documented as being ineffective prior to the use of coercion. For example, if a non-coercive measure, such as differential reinforcement of other behavior (DRO) or differential reinforcement of alternative behavior (DRA) (Cooper, Heron \& Heward 2007), is documented as ineffective, then the act allows for more restrictive measures involving the use of force and/or coercion (e.g. locks on a refrigerator to prevent overeating, physical restraint to prevent self-injurious behavior etc.). This act does not include forced treatment of challenging behavior or forced use of medication, only measures inhibiting or preventing the challenging behavior. Exposure therapy would be an example of treatment. However, the act emphasizes non-coercive measures and proactive strategies, 
which have similarities with the treatment of challenging behavior.

\section{POLAND}

The Polish Constitution prohibits discrimination on any grounds. Article 72 of the Polish Constitution guarantees the right to protection against violence and cruelty. Moreover, the Charter of Rights for Persons with Disabilities (1997) guarantees equal access to all spheres of life. These acts become problematic when confronted with challenging behavior or social maladjustment characteristics of some mental disorders and some disability spectrums. In most cases, instances of challenging behavior that may require coercive force translate to referrals to a special school or special medical facility. Since the 1920s, Maria Grzegorzewska (1964), a Polish pioneer in special education, advocated specialist education for children and youths displaying challenging behavior. She was the first in Poland to demand professional training for special educators, to aid social inclusion for people with SEN (Special Educational Needs). Maladjusted behavior may pose a threat to the safety of self and the public, enhancing the systemic and practical disproportionality in relations of power and helplessness that compromise the above-mentioned guarantees. According to paragraph 18 of the Healthcare Act 1994, supplemented by the Regulation of the Minister of Health 21 December 2018 on the use of direct coercion against a person with mental disorders, force may be used against the will of the person with a minimum discomfort to that person. The use of direct coercion initially should not exceed 4 hours but can be consecutively extended to 6 hours each time it is required for the safety and well-being of the person and their environment. It should cause the least trauma possible and can consist of:

- holding: temporary, short-term immobilization of a person with the use of physical force

- compulsory use of drugs: immediate or prescribed as part of the treatment plan, the introduction of drugs into the body of the person, without the person's consent

- immobilization: overpowering a person with the use of belts, handles, sheets or straitjackets

- isolation: placing a person alone in a closed and appropriately adapted room.

The above legislation pertains only to specialist facilities and to persons that commit an attack against their own or other person's life or health, against the public safety, violently destroy or damage objects in their own environment, seriously prevent the functioning of a psychiatric institution or an organizational unit of social assistance. Although the legislation means to be a protective measure, it creates a moral dilemma for human rights and the rights of patients. Moreover, the recent COVID-19 pandemic reinvigorated the legislation, updating the Act of December 5, 2008 on preventing and combating infections and infectious diseases in humans, with the introduction of 
the article 36, dated 1 September 2020, which allows the use of force against a person who does not undergo compulsory vaccination, sanitary and epidemiological tests, sanitary procedures, quarantine or isolation of compulsory hospitalization, and who is suspected or diagnosed with a particularly dangerous and highly contagious disease thereby posing a direct threat to the health or life of other people. In such instances, direct coercion may consist of holding, immobilizing or forcibly administering drugs. Therefore, the regulations of the Ministry of Health and the legislation on social inclusion (cf. Grung et al. 2021) remain in contradiction to each other.

\section{ROMANIA}

Given the fact that inclusive policies do not have a long tradition in Romania, the institutional culture regarding the management of problematic behaviors is constantly being strengthened. Following a somewhat denialist policy in this regard during the communist period, the challenges of tackling aggressive, adversarial or deeply maladaptive behavior were extreme. In addition to institutional change, there is also a need for extensive campaigns to change public perception of inclusion and problematic behaviors in children with intellectual and developmental disabilities.

Article 50 of the Romanian constitution, added in 2003, expressly provides for complex social protection and equal access to services for people with disabilities (ROU Const., art.50) and has paved the way for legislative and institutional modernization.

The national strategy for the inclusion of children with disabilities, launched in 2005 , finalized the concrete strategies and procedures for organizing inclusive education, educational, social and health services for children with intellectual and developmental disabilities (Gherguț 2005). More and more inclusive schools have been established and the number of special schools decreased, being maintained strictly for children with severe and profound disabilities. Also, clear regulations have been developed regarding the training of specialists, in this case psycho-pedagogues, to safeguard the educational and therapeutic process for children with disabilities. Inclusive policies have increasingly focused on student-centered education, and institutions such as the School Inspectorate and the County Center for Resources and Educational Assistance, along with the Child Protection Directorate, have developed individual plans and allocated as many resources as possible to maximize educational and social inclusion. However, specialists often have difficulty managing problematic situations. Many schools have special spaces designed to relax and calm children who exhibit aggressive behaviors, and psycho-pedagogues are trained to manage and prevent critical situations generated by these behaviors. Medication is used only in critical situations and cannot be imposed institutionally. Parental/guardian consent is required in this regard and this also involves family counselling. The process of including children with intellectual and developmental disabilities in mainstream education is often accompanied by extensive adjustment problems, both on the part of the student and of peers and teachers. In this sense, the special training of teachers in mainstream education is insisted upon in order that they acquire the skills to manage these situations.

The Social Assistance Act of 2011 (ROU 2011: 292) provides assistance measures 
for children with intellectual and developmental disabilities, and regulates the support offered to both children and families. In most cases however, this institutional support is insufficient, especially in cases of problematic behaviors. In this sense, the niche of private services and those provided by NGOs is constantly growing and the demand for services from families is also growing.

\section{UNITED KINGDOM}

Following a media exposé of the treatment of hospitalized patients with learning disabilities and/or autism in the UK, the Transforming Care agenda (NHS England 2015) moved the government's focus to the reduction of hospital beds within Learning Disabilities and Mental Health services. This includes those hospitals belonging to the private and voluntary sectors, as well as the Local Authority and NHS provisions. With fewer beds available and processes in place to ensure that admissions that still do take place are far shorter with an immediate emphasis upon safe discharge, consequentially community learning disability and mental health services are increasingly managing problematic behaviors within the community. Although there has been a reduction of hospitalization it is felt that there has been an increase in the use of psychotropic medication which continues to be heavily relied upon to decrease agitation and anxiety, despite the additional scrutiny applied to such prescribing and the 'Stopping over medication of people with a learning disability, autism or both' (STOMP) campaign led by NHS England (NHS England 2016).

The Care Quality Commission (2017) describes a significant variation between services, and how frequently staff use restrictive practices and physical restraint to de-escalate problematic behavior. Services in the UK are committed to ensuring that the least restrictive practice is observed always, and several important national documents recommend this: e.g. the MIND Report, 'Restraint in Crisis' (2013); Restraint and Restrictive Intervention (DoH 2017); the revised Mental Health Act Code of Practice (2015).

\section{SWEDEN}

In Sweden, there is strong legislative protection of the rights of persons with disabilities. In 2008 the Swedish government ratified, the UN Convention of the Rights for Persons with Disabilities and its Optional Protocol which safeguards the equal access and participation for persons with disabilities. The rights to equal treatment for persons with disabilities is protected by the Swedish Constitution. Chapter 1 , article 2 clearly states that all public institutions shall promote the opportunity for all to participation and equality in society and combat the discrimination of persons on the grounds of disability amongst others. Moreover, the anti-discrimination law from 2008 prohibits discrimination on the basis of disability in all aspects of everyday life (SFS 2008: 567). Though persons with intellectual disability and challenging behavior are not explicitly mentioned in the laws, they are implicitly covered under the heading of disability.

The Swedish system emphasizes a rights-based approach where persons with disa- 
bilities are given the right to access and participate in social welfare services such as education, health care, employment, etc.

Most treatments, rehabilitation and provisions of support to persons with intellectual disabilities and/or challenging behavior are provided with the consent of the individual concerned as prescribed in the Health Care Act (SFS 1982: 763) and the Social Services Act (SFS 2001: 453). However, there may be instances where the need for care and protection of persons may outweigh personal autonomy and involuntary or coercive care be provided. As stated in the Swedish Compulsory Mental Care Act, coercive care may only be used in certain conditions such as if the individual is suffering from a serious mental disturbance, has an absolute need of in-patient psychiatric care due to his/her mental state and general personal circumstances, and objects to such care (Peltro-Piri et al. 2016: 2).

Despite this strict legislation regarding coercion, a Swedish study demonstrates the widespread use of physical restraint in group homes for persons with intellectual disability, especially of persons exhibiting challenging behavior (Lundström et al. 2011). This study identified chair belts as the most commonly used method of physical restraint.

Regarding education, it is estimated that about $1 \%$ of students in the compulsory school system have an intellectual disability (Klang et al. 2019). According to the Swedish Education act (2010), children with intellectual disability in Sweden have the right to be included in the regular education system and support provided to them in their ordinary groups. These students may also be provided support in small groups within the regular education system or attend special schools outside of the regular school system. Students, who due to an intellectual disability are at risk of not meeting the national curriculum standard, may be provided an adapted curriculum (Klang et al. 2019). According to Wilder and Klang (2017), the adapted curriculum can be delivered in both regular and special educational settings. However, a majority of students with IDD in Sweden are provided education in special educational settings outside of the regular education system (Klang et al. 2019). The teaching profession in Sweden is regulated by a specific ethical code of conduct (https://rm.coe.int/vol-4-codes-ofconduct-for-teachers-in-europe-a-background-study/168074cc72). The same applies to medical staff and these have their own code of conduct.

\section{PROFESSION SPECIFIC APPROACHES TO CHALLENGING BEHAVIOR AND SOCIAL INCLUSION}

Professionals working with children and young people with IDD have an ethical responsibility (i.e. professional ethics) and legal obligation (human rights and national legislation) to treat/reduce challenging behavior in order to, among other things, facilitate social inclusion (Grimen 2008; Grung et al. 2021; United Nations 2006).

\section{THE SOCIAL EDUCATOR - NORWAY}

Broadly speaking, the social educator's mandate is to be an 'inclusion agent' - people 
with different kinds of disabilities should experience meaningful lives and positive relationships with other people. Central for the social educator in meeting this mandate is the GAP-model, where the 'GAP' is used as a metaphor for the relationship between an individual's abilities to master their environment and the mastery of the environment over the individual (NOU 2001: 22). The gap is referring to the "space" that occurs when the skills required to manage the environment in a socially acceptable way are lacking. This relational model, which combines the biological and the social perspective on disabilities, allows the social educator to work on both sides of the gap, to increase the individual's abilities to master and to reduce the environments' demands for mastery. On the individual's side, the social educator uses their competency and skills in training of language skills (oral, sign or another alternative language), training of social skills, [behavioral] treatment of self-injurious, aggressive and other kinds of challenging behaviors, and supporting leisure activities and meaningful contact with other significant persons and more. On the 'environment's' side, the social educator uses their competency and skills in structuring the environment (e.g. day plans), removes unnecessary demands, removes physical barriers in the individual's surroundings, trains other professionals in how to meet the needs of children and young adults with IDD (and all others with disabilities), and more. All the measures described here may, alone or in combination, be important measures in limiting the 'gap', and thus reducing problem behavior and increasing the likelihood of experiencing social inclusion. Challenging behavior can, from this perspective, be understood as the individual's response to 'non-standard conditions' in combination with the lack of necessary skills (i.e. a person with IDD and language difficulties self-injures, and the self-injurious behavior is reinforced by attention. The self-injurious behavior may have a mand function (Skinner 1957). It should be mentioned that social educator programs at some universities and university colleges emphasize behavior analysis, while other programs have a more eclectic approach (combining psychological perspectives). However, the relation perspective, as reflected in the GAP-model, is central in all training of social educators independent of psychological perspective (Grung 2016).

\section{THE SPECIAL PEDAGOGUE - POLAND}

The Ministry of Education (Act 1578 of 9.08.2017) regulated the profession of special pedagogue as dedicated to the care, upbringing, and education of children with disabilities, socially maladjusted or at risk of social maladjustment. A special pedagogue is university trained through a 5-year specialist MA program to conduct educational activities in cooperation with other teachers and specialists. They sometimes lead or sometimes participate in lessons and activities run by other teachers and specialists in order to provide support and assistance during integration and group activities. A special pedagogue helps with the choice of materials, forms and methods of teaching the children and youth with disabilities, maladjustment and at risk of maladjustment. They conduct classes adjusted to specific individual developmental needs and psychophysical abilities, including revalidation classes, rehabilitation and socio-therapeutic 
classes. In cooperation with a team of psychologists and pedagogues, the special pedagogue prepares: Individual Multidisciplinary Assessment of the Student's Functioning Level, together with the Individual Educational and Therapeutic Program and its evaluation. Moreover, he/she coordinates the implementation of the recommendations outlined in the special educational needs referral, cooperates with other specialists, external clinics, NGOs and special education institutions as well as the parents. General schools, as well as integrational schools and specialist schools, employ special pedagogues as children with IDD are entitled to study in all these facilities depending on the severity of their disability and the decision made by their parents. In the general and integrational schools, a special pedagogue's therapeutic influence is often supported by school counselors, who are either university trained psychologists or social pedagogues. All these professionals are classed as highly trusted, are highly trained and bound by the professional ethical codes of conduct.

\section{THE PSYCHOPEDAGOGUE - ROMANIA}

In Romania, the primary role in the inclusion of children with disabilities is played by the psychopedagogue, who can specialize in several areas (Roșan 2015). After university training of at least 3 years and obtaining a license in Special Psychopedagogy, the psychopedagogue may choose the following paths:

a. Teaching psychopedagogue. Mainly responsible for adapted teaching activities for children with intellectual and developmental disabilities. He/she works in Inclusive Education Centers or special schools with small groups of children with severe or moderate disabilities and focuses on the transmission of adapted educational content and the training of basic skills.

b. Recovery psychopedagogue. Specialized in individual or group activities aimed at recovering the intellectual, psychomotor and emotional abilities of a child, and the prevention of problematic behaviors. He/she coordinates the individualized intervention plan that aims to focus on the needs and particularities of each child.

c. Psychopedagogue / support teacher. Accompanies children with mild and moderate disabilities included in mainstream education and is responsible for curricular adaptation and ensuring the behavioral and educational adaptation of the child in a mainstream school.

d. Psychopedagogue / itinerant teacher. Travels to the homes of children who encounter major difficulties in travelling to school for a certain period.

The psychopedagogue must adhere to professional ethical conduct and in practice may use implicit (indirect) force, but should rather rely on help from other professionals better equipped to solicit explicit coercive force. In the Romanian context, professionals who work in the state educational system use a general ethical guideline established by the Ministry of Education and Research derived from the National Ed- 
ucation Law 1/2011 and the professionals in the private and the NGO area are subordinate to the Romanian College of Psychologists and the ethical guidelines stated in the 213/2004 Law for the practice of psychology and the procedures derived from it. Therefore, there is a division between state operated and private (NGO) scopes of service provision regarding the ethical guidelines, but they seem to be relatively coherent on ethical aspects.

\section{THE LEARNING DISABILITY NURSE - THE UK PERSPECTIVE}

Key policy documents (Department of Health 2012; NHS England 2015) demonstrate the clear sets of values learning disability nurses aspire to in the UK, with inclusion and person-centered approaches being central to all practices. Similar to that said of social educators, learning disability nurses are agents of inclusion and are often seen as the doorway to equitable health services for a group of people who have historically been vulnerable to inequalities in both health and social care in the UK.

There is currently no single therapeutic approach or service model in the UK that can help at all times to support individuals whose behavior is perceived to be problematic and evidence, particularly around effective services, is poor and/or limited. The National Institute for Clinical Excellence $(2015,2018)$ guidelines recommend Positive Behavior Support (PBS) interventions for adults with intellectual disabilities who exhibit such difficult behaviors. PBS is an understanding of the behavior of an individual. It is based on an assessment of the social and physical environment in which the behavior happens, includes the views of the individual and everyone involved and uses this understanding to develop support that improves the quality of life for the person and others who are involved with them (BILD 2016). The introduction of PBS into government legislation in 2014 indicates a significant shift from simply managing the physical elements of the problematic behaviors and concentrating far more intensely upon the causes and means of addressing the elements of a person's life that it impacts. Nevertheless, the use of coercion is still a recourse when deemed necessary.

\section{THE SPECIAL EDUCATOR/PEDAGOGUE AND SPECIAL EDUCATION TEACHER - SWEDEN}

In Sweden, the special educator/pedagogue and the special education teacher are the key actors who are responsible for the organization and provision of special education at school level. The role of these two professionals is distinctive within the school system. The special pedagogue is primarily responsible for the development of special education at the whole school level, with the goal of achieving inclusion in the school for all. Special educators work at an organizational level to support the development of special educational support that is inclusive with the aim that fewer students in need of special educational support receive this support in separated settings (Berhanu 2014). The special education teacher provides special educational support directly to students individually or in small groups, within their ordinary study group or outside of it. The special education teacher is expected to understand school difficulties at the 
individual level and provide personalized support to the student (Berhanu 2014). The special education teachers have a variety of different specializations including, intellectual disability, language, reading and writing difficulties, mathematics difficulties, visual impairments and hearing impairments. Both special education pedagogues and special education teachers are highly qualified professionals in Sweden, their study programs are at post-graduate level, spanning a period of one and a half years of fulltime studies. Moreover, to qualify for admission into these programs, candidates must have completed the teacher education program and worked for approximately three years (Special pedagogue program SU 2020). These professionals therefore come with experience as regular classroom teachers and with a better understanding of the challenges classroom teachers may experience working with people with IDD. The work of these professionals at school level is not only to strengthen the development and organization of special educational support at the individual, group and school at large, but to do this in a way that is responsive to the requirements of a school for all.

\section{DISCUSSION}

Professions of social trust receive a politically defined mandate to work with vulnerable groups in society. Their overall aim is to foster social inclusion. However, the emphasis on social inclusion may be undermined by loopholes in the support and care systems, in particular by the negative effects of using coercion, which is likely to have a stigmatizing effect and counteracts inclusion efforts. Emerson (2001) describes that some methods of control, inhibit participation and thus, inclusion. For example, people with IDD and challenging behavior are more likely to receive medication. However, the side effects of medication, such as sedation and extrapyramidal syndromes, may inhibit inclusion. Further, control measures involving physical restraints may be socially stigmatizing and such measures often inhibits participation (Emerson 2001). In Poland and in Romania, only graduates of higher education may work in the educational system and therefore also in the special education system. The same applies to medical and therapeutic roles in the Polish and Romanian national health services. In the majority of cases, when private care and NGOs are involved, the professionals come from the same higher education institutions. In Sweden, professionals are expected to adhere to codes of conduct and ethical guidelines that governs their specific professions. For the teacher profession which includes special educators and special education teachers, there are specific codes of conduct and ethical guidelines that have been developed by the teachers' unions. Professional ethics for teachers aim to support the teacher in performing their work in an ethical, professional approach and describes the common values a teacher has and should have (Lärarnas Yrkesetiska Råd 2014) In cases where trained professionals work with persons with IDD, the ethical aspects are standardized (teachers, special educators) but elsewhere, where care may include many other untrained persons (e.g. Ellingsen et al. 2020), the ethical codes may not be of a similar standard or may not be available. Untrained professionals may refer to persons supporting persons with IDD without formal training such as personal assistants. Each profession has their own professional guidelines or code of conduct 
and since different professionals may work with persons with IDD, these codes may differ, as for example for teachers and nurses. In the UK, there are several untrained and unqualified support workers, who work within the field of special education and therapy, especially within the private sector. Nurses and special educators adhere to ethical codes of conduct and are also subject to professional codes of conduct, but many unqualified care-staff are unregulated and do not adhere to a specific code of conduct (Richards 2020). Similar issues were reported in Norway.

This leads to a question: What weight should we put on the value of social inclusion when coercive measures are being assessed? In Norway and other countries there are many staff who lack formal relevant competence. When we know the negative effects of social exclusion (for the persons themselves, their relatives and for the society) why is it accepted that so many lack relevant competence in the services for people with IDD? Relevant competences include, in our view, knowledge about social inclusion, the needs of persons with IDD (e.g. adapted communication), knowledge on how to de-escalate self-harm and violent behavior, awareness of legislation and ethical guidelines. Without relevant competences, formal words written on paper bring little to making social inclusion a reality for people with IDD. A gap may be observed between values that form the basis for legislation related to social inclusion and the need for relevant competences in the services. As described, the employment of a relatively large proportion of people without formally relevant competence increases this gap (Ellingsen et al. 2020). Knowing the negative effects that social exclusion has on a person, we believe that a relevant formal competence is necessary to achieve the goals of social inclusion. So why is the lack of formal competence accepted in these services? Is it simply cost and availability of appropriately trained staff? Relevant competences rely on knowledge of social inclusion and processes that facilitate it, the needs of people with IDD supported by relevant legislation and professional ethics. It is only through relevant education that such skills and knowledge can be learned and understood, and professional ethics are exclusively aimed at individual professions.

\section{CONCLUSION}

Although legislation varies from country to country, specialist training and available support seem to follow the same direction, based on human rights principles: the right to life and health, respect, dignity, and access. Practical solutions shared by specialists prove to be universal, despite professional definitions and linguistic intricacies. Unfortunately, the grey area for inclusion related to the use of physical force remains controversial and unresolved, revealing the limitations and the helplessness of the system when confronted with challenging behavior. We believe that the situation in many cases may be caused by lack of funding for standardized provision of highly trained staff bound by ethical codes and equipped with additional training. We see long-term benefits from raising awareness of how to address challenging behavior in empathetic and humane manners across services. Although there is a difference between IDD and mental illness, the response to challenging behavior appears to be the same when it comes to the use of coercion, including implicit and explicit 
forms, constraints, forceful handling and administration of drugs against the patient's will. Despite advancements in European policy for the rights of people with disabilities (Convention on the Rights of Persons with Disabilities, CRPD), the response to challenging behavior remains insufficiently explored and addressed. This article aims to provoke debate on the gaps between the principles of social inclusion offered by the legislation and the ability to use coercive force that undermines them. Based on our findings we urge stakeholders to invest time and effort in developing alternative strategies for handling challenging behavior and to enhance staff training, so that the awareness of available tools and benefits of using them becomes a norm, not only an aspiration. We also recommend sharing of best practice and raising awareness of tools and techniques available to specialists instead of coercive force.

We conclude with some difficult questions that seem to remain unresolved. How can we incorporate a common code of ethics and practice for professionals working with individuals with IDD? Is it possible to foster social inclusion whilst maintaining the possible use of coercion in cases of IDD? How can a person with IDD trust professionals that use coercion as a method of providing safety, protection, and treatment? What are the alternatives?

FUNDING: This paper received funding from Erasmus+ Project title: "Removal of barriers to social inclusion and social participation for children and young adults with intellectual and developmental disabilities” SIIDD - Cooperation for innovation and the exchange of good practices KA203 - Strategic Partnerships for higher education- Erasmus+ 2019-1-SE01-KA203-060425

CONFLICT OF INTEREST: The authors declare no conflict of interest.

\section{REFERENCES}

Ask, Karl, Ejelöv Ejelöv, \& Pär Anders Granhag. 2019. “Eliciting human intelligence: The effects of social exclusion and inclusion on information disclosure." Journal of Investigative Psychology and Offender Profiling 16(1): 3-17. https://doi.org/10.1002/jip.1516

Bach, Michael \& Lana Kerzner. 2010. „A new paradigm for protecting autonomy and the right to legal capacity.” Retrieved September 10, 2020 (http://www.lco-cdo. org/disabilities/bach-kerzner.pdf).

Bartolo, Paul A., Eva Björck-Åkesson, Climent Giné, \& Mary Kyriazopoulou. 2016. "Ensuring a strong start for all children: Inclusive early childhood education and care." International Perspectives on Inclusive Education 8: 19-35. https://doi. org/10.1108/S1479-363620160000008003

Baumeister, Roy F., Jean M. Twenge, \& Christopher K. Nuss. 2002. “Effects of social exclusion on cognitive processes: Anticipated aloneness reduces intelligent 
thought." Journal of Personality and Social Psychology 83(4): 817-827. https://doi. org/10.1037/0022-3514.83.4.817

Berhanu, Girma. 2014. "Special Education in Sweden today." Advances in Special Education 28: 209-241. https://doi.org/10.1108/S0270-401320140000028014

Bernstein, Michael J. 2016. "Research in social psychology: Consequences of shortand long-term social Exclusion.” Pp. 51-72 in Social Exclusion. Psychological Approaches to Understanding and Reducing Its Impact, edited by P. Riva \& J. Eck. Cham: Springer. https://doi.org/10.1007/978-3-319-33033-4_3

Bigby, Christine. 2012. "Social inclusion and people with intellectual disability and challenging behavior: A systematic review." Journal of Intellectual and Developmental Disability 37(4): 360-374. http://dx.doi.org/10.3109/13668250.2012.721 $\underline{878}$

British Institute of Learning, \& Disabilities. 2016. "The seven key questions about Positive Behaviour Support.” Retrieved September 10, 2020 (https://www.england.nhs.uk/6cs/wp-content/uploads/sites/25/2016/07/bild-key-questions.pdf).

Care Quality Commission. 2017. "The state of care in mental health services 2014 to 2017.” NHS England. Retrieved September 10, 2020 (https://www.england.nhs. uk/ourwork/part-rel/cqc/).

Cooper, John O., Timothy E. Heron, \& William L. Heward. 2007. Applied Behavior Analysis. Second Edition. Upper Saddle River, New Jersey: Pearson Education.

Cox, Alison D., Charmayne Dube, \& Beverley Temple. 2015. "The influence of staff training on challenging behaviour in individuals with intellectual disability: A review." Journal of Intellectual Disabilities 19(1): 69-82. https://doi. org/10.1177/1744629514558075

Danzer, Graham \& Sarah M. Rieger. 2016. "Improving medication adherence for severely mentally ill adults by decreasing coercion and increasing cooperation.” Bulletin of Menninger Clinic 80(1): 30-48. DOI: 10.1521/bumc.2016.80.1.30

Department of Health. 2017. Restraint and restrictive intervention. Retrieved September 10, 2020 (https://www.gov.uk/government/organisations/department-ofhealth-and-social-care).

Department of Health. 2015. The Mental Health Act.

Department of Health. 2012. Transforming care: A national response to Winterbourne View Hospital.

Ellingsen, Karl E., Marit S. Isaksen, \& Dirk Lungwitz. 2020. "Lav kompetanse og utstrakt bruk av deltid truer faglig forsvarlige tjenester til personer med utviklingshemming." [Low competence and extensive use of part-time work threaten professionally sound services for people with developmental disabilities] Fontene forskning 13(1): 18-31. https://fonteneforskning.no/forskningsartikler/lav-kompetanse-og-utstrakt-bruk-av-deltid-truer-faglig-forsvarlige-tjenester-til-personer-med-utviklingshemming-6.19.746982.e7459ba705

Emerson, Eric. 2001. Challenging behavior. Analysis and intervention in people with severe disabilities (2nd ed.). Cambridge: Cambridge University Press.

Filia, Kate M., Henry J. Jackson, Susan M. Cotton, Andrew Gardner, \& Eoin J. Killackey. 2018. "What is social inclusion? A thematic analysis of professional opin- 
ion." Psychiatric Rehabilitation Journal 41(3): 183-195.http://dx.doi.org/10.1037/ pri0000304

Floyd, Kory, Alice E. Veksler, Bree McEwan, Colin Hesse, Justin P. Boren, Dana R. Dinsmore, \& Corey A. Pavlich. 2017. "Social inclusion predicts lower blood glucose and low-density lipoproteins in healthy adults.” Health Communication 32: 1039-1042. http://dx.doi.org/10.1080/10410236.2016.1196423

FO. 2019. Yrkestisk grunnlagsdokument for barnevernpedagoger, sosionomer, vernepleiere og velferdsvitere. Oslo: Fellesorganisasjonen. [FO. 2019. Professional codes for child welfare workers, social workers, social educators and welfare scientist. Oslo: Fellesorganisasjonen]. Retrieved September 10, 2020 (https://www.fo.no/ getfile.php/1324847-1580893260/Bilder/FO\%20mener/Brosjyrer/Yrkesetisk\%20 grunnlagsdokument.pdf).

Gherguț, Alois. 2005. Sinteze de psihopedagogie specială. [Synthesis of Special Education]. Iași: Polirom.

Goffman, Erving. 1971 [1961]. Asylums: Essays on the Social Situation of Mental Patients and Other Inmates, 3rd edn. London: Penguin Books.

Grimen, Harald. 2008. “Profesjon og kunnskap.” [Profession and knowledge] Pp. 71-85 in Profesjonsstudier [Studies of professions], edited by A. Molander \& L. Terum. Oslo: Universitetsforlaget.

Grung, Rolf Magnus. 2016. “The role of the social educator.” Learning Disability Practice 19(10): 24-26. doi:10.7748/ldp.2016.e1810

Grung, Rolf Magnus, Michael Brown, Samuel Abdulla, Julien-Ferencz Kiss, Florica Ortan, Anna Odrowaz-Coates et al. 2021. "Social inclusion in seven European countries: A reflection on the experiences of an Erasmus+ intensive programme." Learning Disability Practice. DOI: 10.7748/ldp.2020.e2120

Helse- og omsorgstjenesteloven. 2011. Lov om kommunale helse- og omsorgstjenester m.m. (LOV-2011-06-24-30). [Health- and care service act. (2011). The Norwegian Act of municipal health- and care services. (ACT-2011-06-24-30)]. Retrieved September 10, 2020 (https://lovdata.no/dokument/NL/lov/2011-06-24-30).

Helsedirektoratet. 2015. Pasient- og brukerrettighetsloven med kommentarer. (RundskrivIS-2015-8). [The Norwegian Directorate of Health(2015).The Patientsand Users Rights Act with comments. (Circular IS-2015-8). Retrieved September 10, 2020 (https://www.helsedirektoratet.no/rundskriv/pasient-og-brukerrettighetsloven-med-kommentarer).

Holden, Borge \& Jens Petter Gitlesen. 2006. "A total population study of challenging behavior in the county of Hedmark, Norway: Prevalence, and risk markers." Research in Developmental Disabilities 27(4): 456-465. https://doi.org/10.1016/j. ridd.2005.06.001

Hem, Marit H., Bert Molewijk, \& Reidar Pedersen. 2014. "Ethical challenges in connection with the use of coercion: a focus group study of health care personnel in mental health care." BMC Med Ethics 15: 82. https://doi.org/10.1186/1472-6939$\underline{15-82}$

Hem, Marit H., Elisabeth Gjerberg, Tonje L. Husum, \& Reidar Pedersen. 2018. “Ethical challenges when using coercion in mental healthcare: A systematic literature re- 
view." Nursing Ethics 25(1): 92-110. https://doi.org/10.1177/0969733016629770 Klang, Nina, Kerstin Göransson, Gunilla Lindqvist, Claes Nilholm, Susanne Hansson, \& Karin Bengtsson. 2020. "Instructional Practices for Pupils with an Intellectual Disability in Mainstream and Special Educational Settings." International Journal of Disability, Development and Education 67(2): 151-166. https://doi.org/10.1080 $\angle 1034912 X .2019 .1679724$

Kunnskapsdepartmentet. 2019. Forskrift om nasjonal retningslinje for vernepleierutdanning (FOR-2019-03-15-411). [The Norwegian Ministry of Education and Research. Regulations on national guidelines for social educator education (FOR2019-03-15-411)] Retrieved September 10, 2020 (https://ovdata.no/dokument/ SF/forskrift/2019-03-15-411).

Lärarnas Yrkesetiska Råd. 2014. Lärares Yrkesetik.: ett stöd för introduktionsperioden. Stockholm.

Lundström, Mats O., Helena Antonsson, Stig Karlsson, \& Ulla H. Graneheim. 2011. "Use of Physical Restraints with people with Intellectual Disabilities Living in Sweden's Group Homes." Journal of Policy and Practice in Intellectual Disabilities 8(1): 36-41.

MIND. 2013. Mental health crisis care: physical restraint in crisis - A report on physical restraint in hospital settings in England. Retrieved September 10, 2020 (https:// www.mind.org.uk/media/197120/physical_restraint_final_web_version).

National Education Law. 1/2011. Romania. Retrieved September 10, 2020 (http://egislatie.just.ro/Public/DetaliiDocument/125150).

National Education Law. 213/2004. Romania. Retrieved September 10, 2020 (http:// legislatie.just.ro/Public/DetaliiDocument/52375\#).

NHS England. 2016. "Stopping over medication of people with a learning disability, autism or both (STOMP).” Retrieved September 10, 2020 (https://www.england. nhs.uk/learning-disabilities/improving-health/stomp/).

NICE. 2015. Challenging behavior and learning disabilities: prevention and interventions for people with learning disabilities whose behavior challenges (NG11). London: National Institute for Health and Care Excellence.

NICE. 2018. Learning disabilities and behavior that challenges: service design and delivery (NG93). London: National Institute for Health and Care Excellence.

Norvoll, Reidun, Marit H. Hem, \& Reidar Pedersen. 2017. “The Role of Ethics in Reducing and Improving the Quality of Coercion in Mental Health Care." HEC Forum 29(1): 59-74. DOI: $10.1007 / \mathrm{s} 10730-016-9312-1$

NOU 2019: 14. 2019. Tvangsbegrensningsloven - Forslag til felles regler om tvang og inngrep uten samtykke i helse- og omsorgstjenesten. [NOU 2019: 14. (2019). The Coercion Limitation Act - Proposal for common rules on coercion and intervention without consent in the health and care service] Retrieved September 10, 2020 (https://www.regjeringen.no/no/dokumenter/nou-2019-14/id2654803/ sec2).

NOU 2001: 22. 2001. Fra bruker til borger-En strategi for nedbygging av funksjonshemmende barrierer. Sosial- og helsedepartementet. [From user to citizen A strategy for elimination of disabling barriers. Ministry of Social Affairs and 
Health] Retrieved September 10, 2020 (https://www.regjeringen.no/no/dokumenter/nou-2001-22/id143931/?ch=1).

Odrowąż-Coates, Anna \& Katarzyna Szostakowska. 2021. "Social pedagogy vs social work in Poland." International Journal of Social Pedagogy 10(1): 3. https://doi. org/10.14324/111.444.ijsp.2021.v10.x.003

Opplærinngslova. 1998. Lov om grunnskolen og den vidaregåande opplæringa (LOV1998-07-17-61). [The Education Act. (1998). The Norwegian Act of primary school and high school (ACT-1998-07-17-61) Retrieved September 10, 2020 (https:// lovdata.no/dokument/NL/lov/1998-07-17-61).

Parodi, Giuliana \& Dario Sciulli. 2012. Social Exclusion. Short and Long Term Causes and Consequences. Heidelberg: Physica-Verlag Heidelberg.

Pasient- og brukerrettighetsloven. 1999. Lov om pasient- og brukerrettigheter (LOV1999-07-02-63). [Patients- and Users Rights Act (1999). The Norwegian Act on Patients- and Users Rights (ACT-1999-07-02-63)] Retrieved September 10, 2020 (https://lovdata.no/dokument/NL/lov/1999-07-02-63).

Pelto-Piri,Veikko, Lars Kjellin, Christina Lindvall, \& Ingemar Engström. 2016. "Justifications for coercive care in child and adolescent psychiatry, a content analysis of medical documentation in Sweden." BMC Health Services Research 16: 66. https://doi.org/10.1186/s12913-016-1310-0

Psykisk helsevernloven. 1999. Lov om etablering og gjennomføring av psykisk helsevern. (LOV-1999-07-02-62). [The Mental Health Care Act. (1999). The Norwegian Act on the establishment and implementation of mental health care. (ACT.199907-02-62)] Retrieved September 10, 2020 (https://lovdata.no/dokument/NL/ lov/1999-07-02-62).

Richards, Michael. 2020. "Whorlton Hall, Winterbourne... person-centred care is long dead for people with learning disabilities and autism." Disability \& Society 35(3): 500-505. https://doi.org/10.1080/09687599.2019.1646530

ROU Const. Art. 50. Retrieved September 10, 2020 (http://www.cdep.ro/pls/dic/ site2015.page?den=act2_1\&par1=2\#t2c2s0sba50).

ROU 2011: 292. 2011. Legea asistenței sociale [Social aistance act] Retrieved September 10, 2020 (https://mmuncii.ro/j33/images/Documente/Legislatie/Assistenta-sociala-2018/Legea_asistentei_sociale_18012018.pdf).

Roșan, Adrian. 2015. Psihopedagogie special. Modele de evaluare și intervenție [Special psycho-pedagogy. Models of evaluation and intervention] Iași: Polirom.

Simó-Pinatella, David, Cristina Mumbardó-Adam, Elisabeth Alomar-Kurz, George Sugai, \& Brandi Simonsen. 2019. "Prevalence of Challenging Behaviors Exhibited by Children with Disabilities: Mapping the Literature.” Journal of Behavioral Education 28(3): 323-343. https://doi.org/10.1007/s10864-019-09326-9

Sjöstrand, Manne, Lars Sandman, \& Petter Karlsson. 2015. "Ethical deliberations about involuntary treatment: interviews with Swedish psychiatrists." BMC Med Ethics 16: 37. https://doi.org/10.1186/s12910-015-0029-5

Skinner, Burrhus F. 1957. Verbal Behavior. New York: Appleton Century-Crofts.

Special pedagogue program SU. 2020. Retrieved September 10, 2020 (https://www. su.se/sok-kurser-och-program/uqspp-1.412477?open-collapse-boxes=pro- 
gram-detail,programme-application).

Stevens, Alex. 2012. "The ethics and effectiveness of coerced treatment of people who use drugs." Human Rights and Drugs 2(1): 7-16.

Syrjämäki, Aleksi H. \& Jari K. Hietanen. 2019. "The effects of social exclusion on processing of social information - A cognitive psychology perspective." British Journal of Social Psychology 58(3): 730-748. https://doi.org/10.1111/bjso.12299

Twenge, Jean M., Roy Baumeister, Dianne Tice, \& Tanja S. Stucke. 2001. "If you can't join them, beat them: Effects of social exclusion on aggressive behavior." Journal of Personality and Social Psychology 81(6): 1058-1069. https://doi. org/10.1037/0022-3514.81.6.1058

United Nations. 2006. Convention on the rights of people with disabilities (CRPD). Retrieved September 10, 2020 (https://www.un.org/development/desa/disabilities/ convention-on-the-rights-of-persons-with-disabilities.html).

Wilder, Jenny \& Nina Klang. 2017. "Sweden.” Pp. 104-118 in The Praeger international handbook of special education, edited by M. Wehmeyer \& J. Patton. Santa Barbara: ABC-CLIO.

Wilkinson, Richard G. \& Michael Marmot. 1998. Social determinants of health: The solid facts. Copenhagen: WHO Regional Office for Europe. Retrieved September 10, 2020 (https://apps.who.int/iris/handle/10665/108082).

World Health Organization. 2020. International statistical classification of diseases and related health problems (11th ed.). Retrieved September 10, 2020 (https:// icd.who.int). 


\section{BIOGRAPHICAL NOTE}

Rolf Magnus Grung, Associate Professor at the Department of Behavioral Science, OsloMet.

Anna Odrowąż-Coates, $\mathrm{PhD}$ is the Chairholder of the UNESCO/Janusz Korczak Chair in Social Pedagogy, and an associate professor at the Insitute of Education at the Maria Grzegorzewska University in Warsaw, Poland.

Jude K. Tah, PhD. Assistant Professor at the Department of Special Education, Stockholm University, Stockholm, Sweden.

Paul Maloret, MA, BA (Hons), PGDip, PGCE, Dip HE, RNLD, Head of the Centre for Learning Disability Studies (tCLDS), University of Hertfordshire.

Julian Ferencz Kiss, PhD in Psychology, lecturer at Teacher Training Department at University of Oradea, Romania.

Florica Ortan, PhD in Educational Sciences, Director and Professor at Teacher Training Department at University of Oradea, Romania.

OPEN ACCESS: This article is distributed under the terms of the Creative Commons Attribution Non-commercial License (CC BY-NC 4.0) which permits any non-commercial use, and reproduction in any medium, provided the original author(s) and source are credited.

ARTICLE HISTORY: Received 2021-09-02 / Accepted 2021-10-19 
